\title{
Correction to: Treatment strategy for atypical ulnar fracture due to severely suppressed bone turnover caused by long- term bisphosphonate therapy: a case report and literature review
}

Kensaku Abe ${ }^{1}$, Hiroaki Kimura ${ }^{1 *}$, Norio Yamamoto ${ }^{2}$, Shingo Shimozaki ${ }^{1}$, Takashi Higuchi ${ }^{1}$, Yuta Taniguchi ${ }^{1}$, Takaaki Uto ${ }^{1}$ and Hiroyuki Tsuchiya ${ }^{2}$

Correction to: BMC Musculoskelet Disord 21, 802 (2020)

$$
\text { https://doi.org/10.1186/s12891-020-03824-y }
$$

Following publication of the original article [1], the authors noticed that the corresponding author was published incorrectly. The correct corresponding author is Dr. Hiroaki Kimura.

The original article [1] has been updated.

\section{Author details}

'Department of Orthopaedic Surgery, Japanese Red Cross Kanazawa Hospital, 2-251 Minma, Kanazawa 921-8162, Japan. ${ }^{2}$ Department of Orthopaedic Surgery, Graduate School of Medical Sciences, Kanazawa University, 13-1 Takara-machi, Kanazawa 920-8641, Japan.

Published online: 05 January 2021

\section{Reference}

1. Abe K, Kimura H, Yamamoto N, et al. Treatment strategy for atypical ulnar fracture due to severely suppressed bone turnover caused by long-term bisphosphonate therapy: a case report and literature review. BMC Musculoskelet Disord. 2020;21:802 https://doi.org/10.1186/s12891-02003824-y.

The original article can be found online at https://doi.org/10.1186/s12891020-03824-y.

* Correspondence: hiroaki030301@yahoo.co.jp

'Department of Orthopaedic Surgery, Japanese Red Cross Kanazawa Hospital, 2-251 Minma, Kanazawa 921-8162, Japan

Full list of author information is available at the end of the article

(C) The Author(s). 2021 Open Access This article is licensed under a Creative Commons Attribution 4.0 International License, which permits use, sharing, adaptation, distribution and reproduction in any medium or format, as long as you give appropriate credit to the original author(s) and the source, provide a link to the Creative Commons licence, and indicate if changes were made. The images or other third party material in this article are included in the article's Creative Commons licence, unless indicated otherwise in a credit line to the material. If material is not included in the article's Creative Commons licence and your intended use is not permitted by statutory regulation or exceeds the permitted use, you will need to obtain permission directly from the copyright holder. To view a copy of this licence, visit http://creativecommons.org/licenses/by/4.0/ The Creative Commons Public Domain Dedication waiver (http://creativecommons.org/publicdomain/zero/1.0/) applies to the data made available in this article, unless otherwise stated in a credit line to the data. 